\title{
Occurrence and Abundance of Spiders in Various Agricultural Formations at Sohag Governorate, Egypt
}

\author{
El-Gepaly, H. M.K.H.; Gihan M. E. Sallam; Azza A. Mohamed and Safaa M. Abdel-Aziz
}

Plant Protection Research Institute (P.P.R.I.), Agricultural Research Center (A.R.C.), Egypt. elgepaly@ gmail.com.

\begin{abstract}
An update of the spider species associated with the most cultivated crops in Shandaweel district, Sohag Governorate, Egypt, with a focus on spider's incidence in dominant and stable habitats in the district; weeds, hlafa grass, citrus trees and ornamental plants during 2016 and 2017 years were illustrated. 18 families, 27 genera and 21 species were identified from 951 individuals (471 males \& 480 females) and 2057 immature with total numbers of 3003 individuals during the study period. Salticidae, Cheiracanthiidae and Dictynidae families were the most dominant with frequency percentage of $38.86 \%, 11.52 \%$ and $10.86 \%$ respectively. Some families identified to genus or family level only like Oecobiidae, Oxyopidae, Pisauridae and Tetragnathidae. This study was also conducted to estimate the population fluctuation of spider families in Sohag Governorate over the two successive years, 2016 and 2017. The spider families reached the highest peaks on weeds in June by 115 and 116 individuals during 2016 and 2017 years respectively, on Citrus in February by 93 and 31 individuals during 2016 and 2017 respectively, on Halfa grass in 2016 November by 99 individuals and in 2017 August by 50 individuals, finally on ornamental plants in 2016 September by 90 individuals and on July 2017 by 134 individuals. Fifteen species were recorded as a new locality record from Sohag Governorate. These species were Argiope lobata, Neoscona subfusca, Nigma conducens, Poecilochroa pugnax, Sengletus extricatus, Plexippus paykulli, Euryopis episinoides, Kochiura aulica, Steatoda erigoniformis, Theridion incanescens, Theridion melanostictum, Theridion spinitarse, Runcinia grammica, Thomisus spinifer and Uloborus walckenaerius.
\end{abstract}

Key words: Occurrence, abundance, survey, population fluctuation, Spider, Sohag Governorate, Egypt.

\section{INTRODUCTION}

Although spiders (Order: Araneae) regarded as carnivorous, the jumping spider, Bagheera kiplingi (Salticidae) consumes over $90 \%$ of its food needs from vegetarian source (Meehan et al., 2008 \& 2009). Spiders spread all the atmosphere of the Earth and reach a height of 5000 meters from the sea level (Foelix, 1996). Globally, more than 47,876 spider species were listed (World Spider Catalog, 2018). Locally in Egypt, 41 families followed by 204 genera and 405 species of spiders were recorded (ElHennawy, 2017a). Survival potential, searching ability, wide host range, adapting for food limitation and low metabolic rate make spiders as model predator (Riechert \& Lockely, 1984 and Rajeswaran et al., 2005). They are at the top of lower food web in any ecosystem under favorable conditions, they can reach max. densities of up to 1000 individuals $/ \mathrm{m}^{2}$ (Riechert, 1981) and eat up more than $10 \mathrm{~g} / \mathrm{m}^{2}$ of insects and other arthropods.

Spider species abundance was descripted in a variety of agro-ecosystems (Costello, 1997 and Hendawy \& Abul-Fadl, 2004), and described as effective predators of other arthropods which live together in agricultural ecosystems (Riechert \& Lockley, 1984; Nyffeler \& Benz, 1987; Malony et al., 2003; Ibrahim et al., 2012 and Sallam \& Abd El-Azim, 2016).

Perspectives differed in the biological value of spiders in ago-ecosystems, where they are subject to intra guild predation (IGP) with other insectivorous (Hodge, 1999) and directly limits the populations of other predators (Wagner \& Wise, 1996 and Wissinger et al., 1996), perhaps as a result of spiders kill more than they consume including other insectivorous which share the same trophic niche (Greenstone, 1999). Insectivorous interactions like to be indistinct, arthropod communities in agro-ecosystems are simplified compared to natural ecosystems, where predators, preferring to consume certain prey species (McPeek, 1990 and Power et al., 1992). In contrast, control of herbivore populations may disrupt by the higher positions predators' in the trophic web. (Rosenheim et al., 1993). Diversity of agricultural infrastructure results in increased opportunities for predators and consequently improved bio pest control. It includes several microhabitats and provides a stable food source for spiders dwelling on them (Southwood, 1978) which correlated with vegetation cover (McDonald, 2007). The beneficial role of the spiders might be interpreted by the low population of the pests when they appeared. Accordingly, conservation of these spider species is crucial to keep the natural balance in different ecosystems, Hendawy and Abul-Fadl (2004).

Our study aims to give an update of the spider species associated with the most cultivated crops in Shandaweel district, Sohag Governorate, Egypt, with a focus on spider's incidence in weeds, hlafa grass, citrus trees and ornamental plants as dominant and stable habitats for spiders during 2016 and 2017 years. It is necessary to make continuous seasonal survey of all arachnid species to know how many species are living there to elucidate their ecological role and their importance in this specific area. 


\section{MATERIALS AND METHODS}

The study was conducted at Shandaweel Agricultural Research Station Farms $\left(26^{\circ} 38^{\prime} 01.6^{\prime \prime} \mathrm{N}\right.$, $\left.31^{\circ} 39^{\prime} 09.2^{\prime \prime} \mathrm{E}\right)$, which characterized by its' nearby to the Nile River, and the diversity of vegetation of both permanent (trees and orchards) or seasonal field crops and vegetable plants. These plantations are interspersed with many bridges and canals that have both permanent and seasonal weeds on their edges.

Sampling of plants: Spiders were randomly gathered from eighteen different host plants, (Figs, Grape, Palm, Mango, Pomegranate, Buckthorn, Cotton, Sorghum, Feed cowpea, Millet, Peanuts, Eggplant, Pepper and Tomato). Furthermore, (Weeds, Halfa grasses, Ornamental plants and Citrus Orchard) and obtained for population density investigation. Table (1) illustrates the common, scientific names and description of the host plants.

Sampling procedure: Sampling collected twice monthly, between 9:00 to 11:00 AM, for two years, from early January 2016 till late December 2017 using three methods for collecting.

\section{Collection methods were:}

1- Sweeping net: One of the easiest ways to get large numbers of spiders is by using a sweeping net five times over the plants then picking the spiders from among the insects gathered with them by hand, (Ibrahim et al., 2012).

2- Beating net (branch shaking): Spiders collected from branches, leaves and flowers by shaking the plants on a cloth or a shake sheet (Sallam, 2002). This method is referred as the drop cloth method. Five plants were shacked over the shaking white cloth $(60 \times 100 \mathrm{~cm}$.) weekly during the surveying period. Five trees were randomly selected and 510 branches of each tree were shaken five times for each sample.

3- Hand sorting method: The hand sorting method was used to pick the individuals found around each plant and under stones besides these trees and individually kept in plastic vials. Ground spiders were collected by hand within the area of a square meter around each tree selected for shaking.

Collections were carried out at random in the selected habitats. All specimens were transferred to the laboratory for counting and identification after then putting in $9 \mathrm{~cm}$ vials filled with $70 \%$ ethyl alcohol and droplets of glycerin and labeled with locality, habitat and collection date. Identification of genera and species was carried out by Dr. Gihan Sallam who identified the collected spiders to family, genus level and species if possible and confirmed by colonel Hisham Kamal El-Din El-Hennawy

Table (1): Common, Scientific names and Description of the Weeds, Ornamental plants and Citrus trees

\begin{tabular}{|c|c|c|c|}
\hline & Common name & Scientific name & Description \\
\hline \multirow{13}{*}{$\frac{n}{8}$} & Field bindweed & Convolvulus arvensis $\mathrm{L}$. & \multirow{4}{*}{ Perennial and leaves broader } \\
\hline & Butterweed & Conyzadio scoridis (L.) & \\
\hline & Camelthorn & Alhagi maurorum Medik. & \\
\hline & Bukkan & Phyla nodiflora (L.) & \\
\hline & Coco grass & Cyperus rotundus $\mathrm{L}$. & \multirow{4}{*}{ Perennial and leaves narrower } \\
\hline & Cogon grass & Impreta cylindrica (L.) P. Beauv. & \\
\hline & Spanish cane & Arundo donax $\mathrm{L}$. & \\
\hline & Bermuda grass & Cynodon dactylon (L.) Pers. & \\
\hline & European black Nightshade & Solanum nigrum L. & \multirow{2}{*}{ Annualand leaves broader } \\
\hline & Rough cocklebur & Xanthium strumarium L. & \\
\hline & Spiny sandbur & Cenchrus echinatus L. & Annualand leaves narrower \\
\hline & Sweet clover & Melilotus indicus (L.) All. & \multirow{2}{*}{ leaves broader } \\
\hline & Bishop's weed & Ammi majus L. & \\
\hline \multirow{14}{*}{ 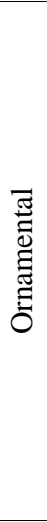 } & Basil & Ocimum basilicum L. & Edges \\
\hline & Thuja & Thuja orientalis L. & Shrub \\
\hline & Duranta "Gold" & Duranta repens $\mathrm{L}$. & Edges \\
\hline & Bottlebrush & Callistemon sp. R.Br. & Shrub \\
\hline & Amaranthus & Amaranthus caudatus L. & Winter annual \\
\hline & Zinnia & Zinnia elegans (Jacq.) Kuntze & Summer annual \\
\hline & Roses & Rosa sp. L. & Shrub \\
\hline & Nerium & Nerium oleander L. & Shrub \\
\hline & Geraniums & Geraniums sp. L'Hér. & bedding plants \\
\hline & Poinciana & Poinciana regia (Boj. ex Hook.) & Perennial trees \\
\hline & Ficus & Ficus nitida $\mathrm{L}$. & Perennial trees \\
\hline & Camel's foot tree & Bauhinia variegate (L.) Benth. & Perennial trees \\
\hline & Dalbergiasisso & Dalbergia sisso Roxb. & Perennial trees \\
\hline & Gazania & Gazania sp. (L.) Gaertn. & Groundcover \\
\hline \multirow{4}{*}{$\stackrel{\infty}{\Xi}$} & Orange & Citrus aurantium (L.) Osbeck & \multirow{3}{*}{ small evergreen tree } \\
\hline & Mandarin & Citrus reticulata Blanco, 1837 & \\
\hline & Lemon & Citrus limon (L.) Osbeck & \\
\hline & Narang & Citrus aurantium L., 1753 & Hedgerow \\
\hline
\end{tabular}


(Arachnid Collection of Egypt). The identification of specimens was executed in the light of available taxonomical knowledge followed the systems used by Petrunkevitch (1939), Kaston (1978), Jocqué \& Dippenaar-Schoeman (2006) and El-Hennawy (2017b). The specimens were preserved in the Spider Research Laboratory, Fruit Acarology Department, Plant Protection Research Institute, A.R.C.

\section{RESULTS AND DISCUSSION}

\section{Survey:}

Various plants were selected to catch spiders according to vegetation in the Shandaweel Research Station Farms, Sohag governorate for two years, from early January 2016 till late December 2017. Table (2) shows the total number of spider families and/or species, identified as much as possible, obtained from the study area which include, Horticulture; Figs, Grape, Palm, Mango, pomegranate and Buckthorn, also various field and vegetable crops; Cotton, Sorghum, Feed Cowpea, Millet, Peanuts, Eggplant, Pepper and Tomato, furthermore; Weeds, Halfa grasses, Ornamental plants and Citrus trees were selected for spider diversity. Spider adults recorded were 951 individuals (471 males \& 480 females) whoever, immature stages of spiders recorded 2057 individuals with total numbers of 3003 individuals during the study period, as shown in table (2). Variation of surveyed host plants resulted diversity of 21 species identified belonging to 27 genera and 18 families. Recorded families through the study period were, Araneidae, Dictynidae, Eresidae, Cheiracanthiidae, Filistatidae, Gnaphosidae, Linyphiidae, Lycosidae, Oecobiidae, Oxyopidae, Philodromidae, Pisauridae, Salticidae, Scytodidae, Tetragnathidae, Theridiidae, Thomisidae and Uloboridae. In Egypt these results agree with Rizk et al., (2012) who surveyed some medical and ornamental plants in Fayoum and recorded total of 315 spiders of 22 species belonging to 21 genera and 15 families. Moreover, in Sohag governorate presence 23 spider species belonging to 20 genera and 19 families were collected from economic plants by Metwally et al., 2002. Furthermore, Sallam (2002) recorded 17 families including 23 genera and more than 25 species, from which only 13 species were identifiable in four governorates; El-Qalyubia, El-Sharqia, El-Fayoum and Beni-Suef. In Italy, Angeli et al. (1996) recorded over 60 spider species representing 18 families in six apples and two pears orchards in Trentio. In South Africa, Berg et al. (1992) collected 3054 spiders represented 21 families in an unsprayed citrus orchard on the transverse louvered.

Data in table (2) represent the classified species and families with their numbers, \% frequency and host plants. It's clear that, Salticidae was the dominant family with individual number of 1167 spiders with frequency of $38.86 \%$ and represented by five species; Ballus sp., Heliophanillus sp., Plexippus paykulli, Thyene imperialis and Thyene sp., followed by the family Cheiracanthiidae with frequency $11.52 \%$ and represented by one species, Cheiracanthium isiacum, followed by the family of Dictynidae with frequency $10.86 \%$ and represented by one species, Nigma conducens, followed by the family Araneidae with frequency $9.62 \%$ and represented by four species; Argiope lobate, Argiope sp., Cyrtophora citricola and Neoscona subfusca, then family Thomisidae with frequency $9.26 \%$ and represented by the three species; Runcinia sp., Runcinia grammica and Thomisus spinifer, then family Theridiidae with frequency $7.29 \%$ and represented by the seven species; Kochiura aulica, Steatoda erigoniformis, Theridion incanescens, Theridion melanostictum, Theridion sp. and Theridion spinitarse, finally the family of Philodromidae with frequency $6.76 \%$ and represented by the four species; Pulchellodromus glaucinus, Thanatus sp., Thanatus albini and Philodromus sp. Berg et al. (1992) indicated that, the Salticidae was the dominant family with frequency $34.4 \%$ followed by the Theridiidae with frequency $21.9 \%$, Thomisidae with frequency $11.9 \%$, Araneidae with frequency $7.9 \%$ and Clubionidae with frequency $7.0 \%$ in an unsprayed citrus orchard.

Some families are identified to the genus or the family level only; those families were Filistatidae with frequency of $0.03 \%$, Oecobiidae with frequency of $0.17 \%$, Oxoyopidae with frequency of $0.57 \%$, Pisauridae with frequency of $0.17 \%$, Scytodidae with frequency of $0.03 \%$ and Tetragnathidae with frequency of $0.13 \%$. EI-Heneidy et al. (1996) interpreted these results as the long evolution of spiders, and the scarcity of fossil remains, made them a difficult group to classify. On the other hand, the rest family Linyphiidae with $(0.53 \%)$ frequency percentage was represented by only one species, Sengletus extricatus.

\section{2) Population density:}

In Sohag governorate fortnight examination was conducted over the two successive years from early January 2016 till late December 2017. Selected host plants were: Weeds, Citrus trees, Halfa grasses and Ornamental plants as dominant host plants at the experimental area to evaluate the dominance of spider families. Spider families for each host plant were organized in monthly census in tables. Graphically, the data were dropped in a spider web design whose ribs were months. 
Table (2): Spider species collected from different host plants and its distributions in Sohag Governorate, Egypt

\begin{tabular}{|c|c|c|c|c|c|c|c|}
\hline \multirow{2}{*}{ Families } & \multirow{2}{*}{ Genus, species } & \multicolumn{4}{|c|}{ No. of individuals } & \multirow{2}{*}{$\begin{array}{l}\text { Freq. } \\
\%\end{array}$} & \multirow{2}{*}{ Host Crops } \\
\hline & & $\mathrm{J}$ & $\mathrm{M}$ & $\mathrm{F}$ & Total & & \\
\hline \multirow{5}{*}{$\begin{array}{l}\text { Araneidae Simon, } \\
1895\end{array}$} & Argiope lobate (Pallas, 1772) N.L.R. & 1 & 1 & 2 & 4 & \multirow{5}{*}{9.62} & 9 and 19 \\
\hline & Argiope sp. & 1 & 1 & 1 & 3 & & 9,12 and 19 \\
\hline & Cyrtophora citricola (Forskal, 1775) & 5 & 0 & 3 & 8 & & 12 and 19 \\
\hline & Neoscona subfusca (Koch, 1837) N.L.R. & 2 & 0 & 1 & 3 & & 9 \\
\hline & - & 212 & 30 & 29 & 271 & & $1,3,5,7,9,10,11,12,16,17$ and 19 \\
\hline \multirow{2}{*}{$\begin{array}{c}\text { Dictynidae } \\
\text { Cambridge, } 1871\end{array}$} & Nigma conducens Cambridge, 1876 N.L.R. & 54 & 11 & 39 & 104 & \multirow[b]{2}{*}{10.86} & $3,4,9,10,12$ and 19 \\
\hline & - & 150 & 31 & 41 & 222 & & $\begin{array}{c}1,3,4,6,8,9,10,12,15,17 \\
18 \text { and } 19\end{array}$ \\
\hline $\begin{array}{c}\text { Eresidae } \\
\text { Ausserer, } 1867\end{array}$ & Stegodyphus dufouri (Audouin, 1825) & 1 & 0 & 1 & 2 & 0.07 & 18 \\
\hline \multirow{2}{*}{$\begin{array}{l}\text { Cheiracanthiidae } \\
\text { Wagner, } 1887\end{array}$} & $\begin{array}{l}\text { Cheiracanthium isiacum } \\
\text { (Cambridge, 1874) }\end{array}$ & 2 & 0 & 2 & 4 & \multirow{2}{*}{11.52} & 3 and 17 \\
\hline & - & 299 & 26 & 17 & 342 & & $\begin{array}{c}1,2,3,4,5,7,9,10,11,12,13,14 \\
16,17 \text { and } 19\end{array}$ \\
\hline $\begin{array}{c}\text { Filistatidae Ausserer, } \\
1867\end{array}$ & Filistata sp. & 1 & 0 & 0 & 1 & 0.03 & 12 \\
\hline $\begin{array}{l}\text { Gnaphosidae Pocock, } \\
1898\end{array}$ & $\begin{array}{l}\text { Poecilochroa } \\
\text { pugnax (Cambridge, 1874) N.L.R. }\end{array}$ & 25 & 2 & 3 & 30 & 1.00 & $1,3,4,7,9,10,13,15,18$ and 19 \\
\hline $\begin{array}{c}\text { Linyphiidae } \\
\text { Blackwall, } 1859\end{array}$ & $\begin{array}{l}\text { Sengeletus extricatus (Cambridge, 1876) } \\
\text { N.L.R. }\end{array}$ & 11 & 4 & 1 & 16 & 0.53 & $1,3,5,7,12,13,18$ and 19 \\
\hline $\begin{array}{l}\text { Lycosidae Sundevall, } \\
1833 \\
\end{array}$ & Trocosa sp. & 50 & 0 & 1 & 51 & 1.70 & $1,3,4,9,12,14,17,18$ and 19 \\
\hline $\begin{array}{l}\text { Oecobiidae Blackwall, } \\
1862\end{array}$ & Uroctea sp. & 0 & 5 & 0 & 5 & 0.17 & $1,4,18$ and 19 \\
\hline $\begin{array}{c}\text { Oxoyopidae Thorell, } \\
1870\end{array}$ & & 14 & 1 & 2 & 17 & 0.57 & $3,12,18$ and 19 \\
\hline \multirow{5}{*}{$\begin{array}{l}\text { Philodromidae } \\
\text { Thorell, } 1870\end{array}$} & Pulchellodromus glaucinus Simon, 1870 & 1 & 0 & 1 & 2 & \multirow{5}{*}{6.76} & 19 \\
\hline & Thanatus sp. & 4 & 0 & 0 & 4 & & 19 \\
\hline & Thanatus albini (Audouin, 1825) & 1 & 1 & 1 & 3 & & 9,15 and 18 \\
\hline & Philodromus sp. & 1 & 0 & 1 & 2 & & 19 \\
\hline & - & 177 & 6 & 9 & 192 & & $\begin{array}{c}1,3,4,5,6,7,9,10,12,13,14,15 \\
16,17,17,18 \text { and } 19\end{array}$ \\
\hline $\begin{array}{c}\text { Pisauridae Simon, } \\
1890 \\
\end{array}$ & - & 5 & 0 & 0 & 5 & 0.17 & 12 and 13 \\
\hline \multirow{6}{*}{$\begin{array}{l}\text { Salticidae Blackwall, } \\
\qquad 1841\end{array}$} & Ballus sp. & 6 & 5 & 10 & 21 & \multirow{6}{*}{38.86} & 12 and 19 \\
\hline & Heliophanillus sp. & 13 & 11 & 7 & 31 & & $4,9,12$ and 19 \\
\hline & $\begin{array}{l}\text { Plexippus paykulli (Audouin, 1825) } \\
\text { N.L.R. }\end{array}$ & 0 & 0 & 1 & 1 & & 12 \\
\hline & Thyene imperialis (Rossi, 1846) & 25 & 13 & 7 & 45 & & 9,12 and 19 \\
\hline & Thyene sp. & 13 & 8 & 11 & 32 & & 12 and 19 \\
\hline & - & 632 & 204 & 201 & 1037 & & $\begin{array}{c}1,2,3,4,5,7,8,9,10,12,13,14,15 \\
16,17,18 \text { and } 19\end{array}$ \\
\hline $\begin{array}{l}\text { Scytodidae Blackwall, } \\
1864\end{array}$ & Scytodes sp. & 1 & 0 & 0 & 1 & 0.03 & 3 \\
\hline $\begin{array}{l}\text { Tetragnathidae } \\
\text { Menge, } 1866\end{array}$ & Tetragnatha sp. & 4 & 0 & 0 & 4 & 0.13 & 9 and 14 \\
\hline \multirow{7}{*}{$\begin{array}{l}\text { Theridiidae Sundevall, } \\
1833\end{array}$} & $\begin{array}{l}\text { Kochiura aulica } \\
\text { (Koch, 1838) N.L.R. }\end{array}$ & 18 & 1 & 4 & 23 & \multirow{7}{*}{7.29} & 3 and 16 \\
\hline & $\begin{array}{l}\text { Euryopis episinoides (Walckenaer, 1847) } \\
\text { N.L.R. }\end{array}$ & 0 & 0 & 2 & 2 & & 9 \\
\hline & $\begin{array}{l}\text { Steatoda erigoniformis (Cambridge, 1872) } \\
\text { N.L.R. }\end{array}$ & 1 & 0 & 0 & 1 & & 19 \\
\hline & $\begin{array}{l}\text { Theridion incanescens } \\
\text { Simon, } 1890 \text { N.L.R. }\end{array}$ & 0 & 0 & 2 & 2 & & 1 \\
\hline & Theridium sp. & 2 & 1 & 0 & 3 & & 3 and 9 \\
\hline & $\begin{array}{lll}\text { Theridium } & \text { melanostictium } & \text { O.P.- } \\
\text { Cambridge, } 1876 \text { N.L.R. } & \\
\end{array}$ & 19 & 3 & 6 & 28 & & $3,4,9,17,18$ and 19 , \\
\hline & $\begin{array}{l}\text { Theridion spinitarse Cambridge, } \\
1872 \text { N.L.R. }\end{array}$ & 110 & 10 & 40 & 160 & & $1,2,3,4,7,9,10,12,15,18$ and 19 \\
\hline \multirow{4}{*}{$\begin{array}{l}\text { Thomisidae } \\
\text { Sundevall, } 1833\end{array}$} & Runcinia sp. & 4 & 1 & 0 & 5 & & 12,14 and 18 \\
\hline & $\begin{array}{l}\text { Runcinia grammica } \\
\text { (Koch, 1837) N.L.R. }\end{array}$ & 1 & 0 & 0 & 1 & 026 & 17 \\
\hline & $\begin{array}{ll}\text { Thomisus spinifer Cambridge, } 1872 \\
\text { N.L.R. }\end{array}$ & 25 & 29 & 3 & 57 & 9.26 & $3,7,9,12$ and 19 \\
\hline & - & 131 & 59 & 25 & 215 & & $3,7,9,12$ and 19 \\
\hline Uloboridae Thorell, & $\begin{array}{l}\text { Uloborus walckenaerius Latreille, } 1806 \\
\text { N.L.R. }\end{array}$ & 14 & 0 & 5 & 19 & 1.43 & 3 and 19 \\
\hline & - & 21 & 2 & 1 & 24 & & $3,7,10,12,16$ and 19 \\
\hline & Total & 2057 & 461 & 480 & 2998 & 100 & \\
\hline $\begin{array}{l}\text { Avocado } \\
\end{array}$ & Buckthorn & Cotton & 5 & & & 6 & Feed cowpea \\
\hline Grape & Halfa & Millet & 12 & & amental & 13 & Peanuts \\
\hline Pepper & Pomegranate & Tomato & & & & & \\
\hline & $\mathrm{J}=$ Juvenile $\quad \mathrm{M}=$ Male & $\mathrm{F}=$ & Female & N.L. & $=\mathrm{New}$ & ality & ecord \\
\hline
\end{tabular}


Table (3): Population density of spider families collected from weeds in Sohag Governorate during 2016 and 2017 years

\begin{tabular}{|c|c|c|c|c|c|c|c|c|c|c|c|c|c|}
\hline & \multicolumn{13}{|c|}{2016} \\
\hline & Jan & Feb & Mar & Apr & May & Jun & Jul & Aug & Sep & Oct & Nov & Dec & Total \\
\hline Araneidae & 4 & 4 & 29 & 14 & 1 & 8 & 2 & 7 & 2 & - & - & 1 & 72 \\
\hline Dictynidae & - & - & - & 5 & 3 & - & 3 & 3 & 1 & 5 & 7 & 3 & 30 \\
\hline Cheiracanthiidae & 2 & 4 & 6 & 8 & 9 & 7 & 9 & 8 & 1 & 7 & 10 & 5 & 76 \\
\hline Gnaphosidae & 6 & 8 & 4 & 4 & 4 & 4 & 4 & - & - & - & - & 8 & 42 \\
\hline Linyphiidae & - & - & - & - & - & 2 & 3 & 2 & - & - & - & - & 7 \\
\hline Lycosidae & - & - & - & - & 1 & - & 6 & 2 & - & - & - & - & 9 \\
\hline Oecobiidae & - & - & - & - & 1 & - & - & - & - & - & - & - & 1 \\
\hline Oxyopidae & - & - & - & 2 & 2 & - & 3 & 2 & - & - & - & - & 9 \\
\hline Philodromidae & - & 4 & 2 & 7 & 7 & 4 & 5 & 4 & - & - & - & - & 33 \\
\hline Salticidae & 2 & 7 & 7 & 10 & 15 & 41 & 38 & 31 & 11 & 33 & 24 & 7 & 226 \\
\hline Thomisidae & - & 2 & 2 & 3 & - & 38 & - & 2 & - & 1 & 4 & 2 & 54 \\
\hline Theridiidae & - & - & - & 6 & 9 & 7 & 10 & 4 & - & - & - & 1 & 37 \\
\hline Uloboridae & 2 & - & - & 4 & 4 & 4 & 3 & 2 & - & - & - & 8 & 27 \\
\hline \multirow[t]{3}{*}{ Total } & 16 & 29 & 50 & 63 & 56 & 115 & 86 & 67 & 15 & 46 & 45 & 35 & 623 \\
\hline & \multicolumn{13}{|c|}{2017} \\
\hline & Jan & Feb & Mar & Apr & May & Jun & Jul & Aug & Sep & Oct & Nov & Dec & Total \\
\hline Araneidae & 1 & 6 & 9 & 7 & 3 & 13 & 7 & 9 & 4 & 10 & 5 & - & 74 \\
\hline Dictynidae & - & 4 & 3 & 5 & 2 & 9 & 1 & 3 & 4 & 4 & 6 & 1 & 42 \\
\hline Cheiracanthiidae & 2 & 8 & 7 & 12 & 14 & 26 & 5 & 11 & 3 & 0 & 6 & - & 94 \\
\hline Gnaphosidae & 1 & - & - & 8 & - & 3 & - & 3 & 3 & - & - & - & 18 \\
\hline Linyphiidae & - & - & - & - & - & - & - & - & 0 & 3 & - & - & 3 \\
\hline Lycosidae & - & - & - & - & 2 & 1 & - & - & 3 & 3 & - & - & 9 \\
\hline Oecobiidae & - & - & - & - & 1 & - & - & 2 & - & - & - & - & 3 \\
\hline Oxyopidae & - & - & - & - & - & - & - & - & 1 & 3 & - & - & 4 \\
\hline Philodromidae & - & - & - & - & - & - & - & - & - & - & - & - & - \\
\hline Salticidae & 4 & 10 & 15 & 15 & 23 & 48 & 15 & 16 & 28 & 42 & 15 & 7 & 238 \\
\hline Thomisidae & - & 1 & - & - & 4 & 1 & 3 & 6 & 1 & 1 & 1 & - & 18 \\
\hline Theridiidae & - & 3 & 4 & 3 & 6 & 12 & - & - & - & 2 & - & 1 & 31 \\
\hline Uloboridae & - & - & - & - & - & 3 & - & 2 & 3 & - & - & - & 8 \\
\hline Total & 8 & 32 & 38 & 50 & 55 & 116 & 31 & 52 & 50 & 68 & 33 & 9 & 542 \\
\hline
\end{tabular}

\section{Population density of spider families collected from weeds:}

Thirteen and twelve spider families with annual total number of 623 and 542 individuals were collected from the weeds; Field bindweed, Butter weed, Camel thorn, bukkan, Coco grass, Cogon grass, Spanish cane, Bermuda grass, European black nightshade, rough cocklebur, spiny sandbur, Sweet clover and bishop's weed for 2016 and 2017 respectively . These families were (Araneidae, Cheiracanthiidae, Dictynidae, Gnaphosidae, Linyphiidae, Lycosidae, Oecobiidae, Oxyopidae, Philodromidae, Salticidae, Thomisidae, Theridiidae and Uloboridae). Regarding the family Philodromidae, it appeared in the beginning of the first year in February 2016 with few varied numbers of spider individuals tell August then disappeard and it was absent in 2017. On the other hand, family Salticidae represented the highest annual count (no absence in any month) with 226 and 238 spider individuals in 2016 and 2017 respectively. Cardenas et al. (2006) studying the spider abundance on olive tree canopies in olive orchards, they found four families Thomisidae, Oxyopidae, Salticidae and Theridiidae comprising more than $83 \%$ of the captured specimens, while the family Oecobiidae was rare with an individual in May-2016 and reappeared in an individual in May-2017 then appeared with two individuals in August-2017.

As for the total number of spiders per month, the first sample counted 16 individuals from five families in 2016, and counted 8 individuals from four families in 2017, as months passed census continued to rise, both in numbers and diversity of families, until April2016, where the first peak was recorded by 63 individuals from 10 different families, where the family Araneidae was the most contributing with 14 individuals. Spiders decreased in May-2016 and continued increase in 2017 to form the big peaks in Jun for both by 115 and 116 individuals from nine families in 2016 and 2017, respectively. In the first year, spiders decreased to reach the lowest level in September 2016, by 15 individuals from 4 families, and peaked again for last time in October 2016 by 46 individuals from 4 families. In the second year, spiders formed two peaks in August and October 2017 by 52 and 68 individuals from eight families for 2016 and 2017, respectively. This result is accordance with Sallam (2002) who studied the influence of both temperature and the relative humidity on the population of the spiders in four locations in Egypt and reported that the spider population reached high numbers in the late summer season in Fayoum and 
Beni-Sueif locations; while in Qalubiya location the spider population was high in summer season and extended to Autumn season in Sharkia location on olive, apple and citrus trees. Scheidler (1990) and Wolak, (2000) studied the influence of habitat structure and vegetation architecture on spiders and found higher spider densities on broad plants with many branches than on plants with only few branches and a rather narrow architecture. Ghabbour et al. (1999) and Sallam \& Abd El-Azim (2016) recorded the peak of active population density in August followed by rather high values in September and lower active population density in February during his spider study on some vegetable plants in Menoufia governorate.

\section{B) Population density of spider families collected from Citrus trees.}

Population density of spiders inhabiting Citrus trees (Orange, Mandarin, lemon and Narang) from early January 2016 till late December 2017 years were sorted in table (4) and graphically distributed in figure (2). Thirteen and nine spider families were collected from citrus trees with annual total 550 and 178 spiders in 2016 and 2017 years respectively. The families (Linyphiidae, Lycosidae, Oxyopidae and Scytodidae) were represented by few numbers in 2016 by 5, 2, 1 and 1 individual respectively, while absent in 2017. The data conformed to the typical pattern of few species were represented by many individuals and many species occurred by few individuals (Preston 1948). Of the 550 spiders for the first year, the families Cheiracanthiidae and Dictynidae contributed the highest numbers of spiders by 114 and 105 individuals followed by Salticidae and Theridiidae by 79 and 70 individuals during the period of study, respectively. While, Cheiracanthiidae and Salticidae families continued to appear every month of the first year. These results unlike the second year, the family Salticidae occupied the census by 59 individuals, and it was the only family which continued to appear every month of second year. This result agrees with Mohafez et al. (2010) who studied the survey and seasonal fluctuations of common true spiders inhabiting different orchard trees in Egypt at the two localities at Sohag governorate (Tahta and Temma) which showed that, the population of the spider families, Lycosidae, Miturgidae, Theridiidae and Salticidae were found all over the two-year months, with highest numbers fluctuation nearly to each other in relatively on mango. EI-Heneidy et al. (1996) showed that, total population of the true spiders was highest during 1991 than 1993 cotton seasons. On the other hand, Sallam (1996) and Hussein et al. (1998) observed that the five families Araneidae, Lycoside, Philodromidae, Salticidae and
Theridiidae occurred in all the surveyed locations on citrus trees.

Data in table (4) also showed three peaks for both study years on February, May and October of the first year and on February, April and October of the second year and with total of 93, 72 and 47 individuals and 31, 24 and 19 individuals respectively. These results resembled that of Ghabbour et al. (1999) who showed that, the highest densities of spiders were 4.22, 3.41 and 2.88 spider/trap for caraway, cabbage and onion respectively, during winter season. Cheiracanthiidae and Dictynidae families showed different populations in the two successive years recording 114 and 105 individuals within 2016 year and 13 and only one individual within 2017 year. On the other hand, the individuals of the family Araneidae had two peaks during 2016 year, on February and Jun, by 10 and 14 individuals respectively, Furthermore, in 2017, spider population started to increase reaching highest peak by 14 individuals in February and then, decreased sharply to reach the lowest number by only one individual in December.

El-Sebaay (2003) surveyed the spider species in different orchards (apple, citrus, guava, mango, olive and peach) in six different localities of Ismilia Governorate. Sallam (2002) studied the influence of both temperature degrees and the relative humidity on the population of the true spiders in four survey locations in Egypt and reported that the spider population reached high numbers in the late summer season in Fayoum and Beni-Sueif locations; while in Qalubiya location the spider population was high in summer season and extended to Autumn season in Sharkia location on olive, apple and citrus trees. Breene et al. (1993) collected the spiders from citrus groves from Southern Texas using hand collection aspirator and sweep net during August 1990 to March 1991. Ahmed et al. (2014) observed that Spider population increased gradually during spring months and then a sharp decrease occurred during winter months on pomegranate and orange trees, then the spider populations increased gradually in spring months during the experimental time then gradually decreased during autumn with sharp decline in population in winter months at the two tested localities (Abnob and Badari), Assiut governorate, during the period from April 2013 to March 2014. 
Table (4): Population density of spider families collected from Citrus trees in Sohag Governorate during 2016 and 2017 years

\begin{tabular}{|c|c|c|c|c|c|c|c|c|c|c|c|c|c|}
\hline & \multicolumn{13}{|c|}{2016} \\
\hline & Jan & Feb & Mar & Apr & May & Jun & Jul & Aug & Sep & Oct & Nov & Dec & Total \\
\hline Araneidae & 5 & 10 & 12 & 8 & 1 & 14 & 2 & 5 & - & - & - & - & 57 \\
\hline Dictynidae & 18 & 20 & 18 & 10 & 28 & 5 & 3 & 3 & - & - & - & - & 105 \\
\hline Cheiracanthiidae & 10 & 18 & 14 & 7 & 9 & 12 & 4 & 3 & 3 & 28 & 4 & 2 & 114 \\
\hline Gnaphosidae & 11 & 2 & 4 & 3 & 1 & 1 & - & 2 & 2 & 5 & 1 & 5 & 37 \\
\hline Linyphiidae & - & - & - & - & 2 & - & 1 & - & - & - & - & 2 & 5 \\
\hline Lycosidae & - & - & - & - & - & 1 & - & - & - & 1 & - & - & 2 \\
\hline Oxyopidae & - & - & - & - & - & - & - & - & - & 1 & - & - & 1 \\
\hline Philodromidae & 4 & 3 & - & 7 & - & - & - & - & - & - & - & - & 14 \\
\hline Salticidae & 4 & 13 & 14 & 9 & 4 & 11 & 5 & 4 & 4 & 5 & 4 & 2 & 79 \\
\hline Scytodidae & - & - & - & - & - & 1 & - & - & - & - & - & - & 1 \\
\hline Theridiidae & 13 & 15 & 11 & 6 & 12 & 4 & 2 & 1 & 0 & 2 & 2 & 2 & 70 \\
\hline Thomisidae & - & - & - & - & 2 & 16 & 2 & - & - & 5 & - & 1 & 26 \\
\hline Uloboridae & 3 & 12 & 4 & 3 & 13 & 3 & - & - & - & - & - & 1 & 39 \\
\hline \multirow[t]{3}{*}{ Total } & 68 & 93 & 77 & 53 & 72 & 68 & 19 & 18 & 9 & 47 & 11 & 15 & 550 \\
\hline & \multicolumn{13}{|c|}{2017} \\
\hline & Jan & Feb & Mar & Apr & May & Jun & Jul & Aug & Sep & Oct & Nov & Dec & Total \\
\hline Araneidae & 2 & 14 & 9 & 3 & 1 & 2 & 2 & 1 & - & 3 & 1 & 1 & 39 \\
\hline Dictynidae & - & - & - & - & - & - & 1 & - & - & - & - & - & 1 \\
\hline Cheiracanthiidae & 1 & 1 & 1 & - & 7 & - & 1 & 1 & - & 1 & - & - & 13 \\
\hline Gnaphosidae & - & - & - & - & 1 & - & 1 & 1 & 3 & 4 & 4 & - & 14 \\
\hline Linyphiidae & - & - & - & - & - & - & - & - & - & - & - & - & - \\
\hline Lycosidae & - & - & - & - & - & - & - & - & - & - & - & - & - \\
\hline Oxyopidae & - & - & - & - & - & - & - & - & - & - & - & - & - \\
\hline Philodromidae & 1 & 4 & 3 & - & - & - & - & - & 4 & - & - & - & 12 \\
\hline Salticidae & 3 & 9 & 5 & 8 & 5 & 3 & 4 & 4 & 5 & 6 & 4 & 3 & 59 \\
\hline Scytodidae & - & - & - & - & - & - & - & - & - & - & - & - & - \\
\hline Theridiidae & 1 & 1 & - & 2 & 6 & 4 & 1 & - & - & 4 & 3 & 2 & 24 \\
\hline Thomisidae & - & - & 1 & 1 & 2 & - & - & - & - & - & - & - & 4 \\
\hline Uloboridae & - & 2 & 1 & 1 & 2 & 2 & 1 & - & 2 & 1 & - & - & 12 \\
\hline Total & 8 & 31 & 20 & 15 & 24 & 11 & 11 & 7 & 14 & 19 & 12 & 6 & 178 \\
\hline
\end{tabular}

\section{C) Population density of spider families collected from Halfa grass.}

Ten families (Araneidae, Cheiracanthiidae, Dictynidae, Gnaphosidae, Lycosidae, Philodromidae, Salticidae, Tetragnathidae, Theridiidae and Thomisidae) were recorded inhabiting halfa grass during the study period (table 5), but the family Gnaphosidae was absent in the first year while, recorded in second by 8 individuals. Also the family Tetragnathidae was absent in the second year while, recorded in the first year by 4 individuals. Family Araneidae varied number in the beginning of the first year (2016) to reach the first peak in September with 17 individuals, after that this number decreased then increased to reach the second peak in August with 15 individuals for second year, 2017.

The members of the family Salticidae were present throughout the study period without absence. It was the dominant family recorded in the two successive years, 2016 and 2017 by annual total numbers of 176 and 88 individuals respectively. This family formed three peaks in March, August and November by 11, 58 and 26 individuals respectively, in 2016 year and in February, May and August by 9 , 9 and 14 individuals respectively, in the year 2016.
This result resembled that of Sallam (2002) who showed that the population reached its maximum in August and September during the two successive years (106, 92 individuals in 1997 and 100, 90 in 1998), at average temperature 25.5-27.4 and 28.3$32.2^{\circ} \mathrm{C}$ and relative humidity $59-61$ and $57 \%$ R.H. in the two successive years, respectively. The population then decreased reaching its minimum in January and February. The family Theridiidae fluctuated with few total numbers of 34 and 36 individuals in 2016 and 2017, respectively, and formed one peak on October 2016 by 12 individuals.

In this study, the great difference in dominant spider families abundances species richness and evenness which might be dependent on type of plant dense vegetation or shad and humidity. This result agreed with that of Ghaobour et al. (1999) who found the shade of plants and the available humidity expressed as water requirement for each crop in addition to density of plants / acre directly affected abundance of activity density of soil fauna. Habashy et al. (2005) concluded that, indirectly, the area of surface vegetation affected spider population density and biodiversity, which influenced by microclimate of the plant. 
Table (5): Population density of spider families collected from Halfa grasses in Sohag governorate during2016 and 2017 years

\begin{tabular}{|c|c|c|c|c|c|c|c|c|c|c|c|c|c|}
\hline \multirow{2}{*}{ Families } & \multicolumn{13}{|c|}{2016} \\
\hline & Jan & Feb & Mar & Apr & May & Jun & Jul & Aug & Sep & Oct & Nov & Dec & Total \\
\hline Araneidae & 3 & 6 & 4 & 5 & 3 & 1 & - & 2 & 17 & 9 & - & 8 & 58 \\
\hline Dictynidae & - & - & - & 1 & - & - & 5 & 3 & 7 & 1 & 14 & 4 & 35 \\
\hline Cheiracanthiidae & - & - & 2 & 6 & 2 & - & 3 & 1 & 7 & 2 & 5 & 5 & 33 \\
\hline Gnaphosidae & - & - & - & - & - & - & - & - & - & - & - & - & - \\
\hline Lycosidae & 1 & 1 & 4 & 4 & 1 & - & 1 & - & - & - & 10 & - & 22 \\
\hline Philodromidae & - & - & - & - & - & - & - & - & 6 & 4 & 33 & 10 & 53 \\
\hline Salticidae & 2 & 10 & 11 & 5 & 2 & 4 & 6 & 58 & 26 & 16 & 26 & 10 & 176 \\
\hline Tetragnathidae & - & - & - & - & - & - & - & - & - & 1 & 3 & - & 4 \\
\hline Theridiidae & 2 & - & 4 & 2 & 2 & 5 & - & 1 & 5 & 4 & 3 & 6 & 34 \\
\hline Thomisidae & 1 & 1 & 1 & 2 & 3 & 2 & 2 & 4 & 1 & 12 & 5 & 4 & 38 \\
\hline Total & 9 & 18 & 26 & 25 & 13 & 12 & 17 & 69 & 69 & 49 & 99 & 47 & 453 \\
\hline \multirow{2}{*}{ Families } & \multicolumn{13}{|c|}{2017} \\
\hline & Jan & Feb & Mar & Apr & May & Jun & Jul & Aug & Sep & Oct & Nov & Dec & Total \\
\hline Araneidae & 4 & - & 3 & 3 & 6 & 5 & 4 & 15 & 2 & - & - & - & 42 \\
\hline Dictynidae & - & 3 & 4 & 2 & 4 & - & 2 & 1 & - & - & - & 1 & 17 \\
\hline Cheiracanthiidae & 1 & 7 & 5 & 2 & 3 & 6 & 3 & 10 & 14 & 3 & 2 & 2 & 58 \\
\hline Gnaphosidae & - & - & - & - & 3 & - & 1 & 2 & 1 & 1 & - & - & 8 \\
\hline Lycosidae & 2 & 1 & - & 2 & 1 & 3 & - & - & - & - & - & - & 9 \\
\hline Philodromidae & - & - & 2 & - & 2 & 4 & 1 & - & 4 & 2 & 2 & 4 & 21 \\
\hline Salticidae & 5 & 9 & 5 & 8 & 9 & 7 & 4 & 14 & 13 & 9 & 3 & 2 & 88 \\
\hline Tetragnathidae & - & - & - & - & - & - & - & - & - & - & - & - & - \\
\hline Theridiidae & 5 & 3 & 1 & 3 & 2 & 2 & 4 & 4 & 4 & 3 & 3 & 2 & 36 \\
\hline Thomisidae & 4 & - & 2 & 1 & 1 & 1 & 3 & 4 & - & - & 1 & - & 17 \\
\hline Total & 21 & 23 & 22 & 21 & 31 & 28 & 22 & 50 & 38 & 18 & 11 & 11 & 296 \\
\hline
\end{tabular}

Table (6): Population density of spider families collected from ornamental plants in Sohag governorate during 2016 1nd 2017 years

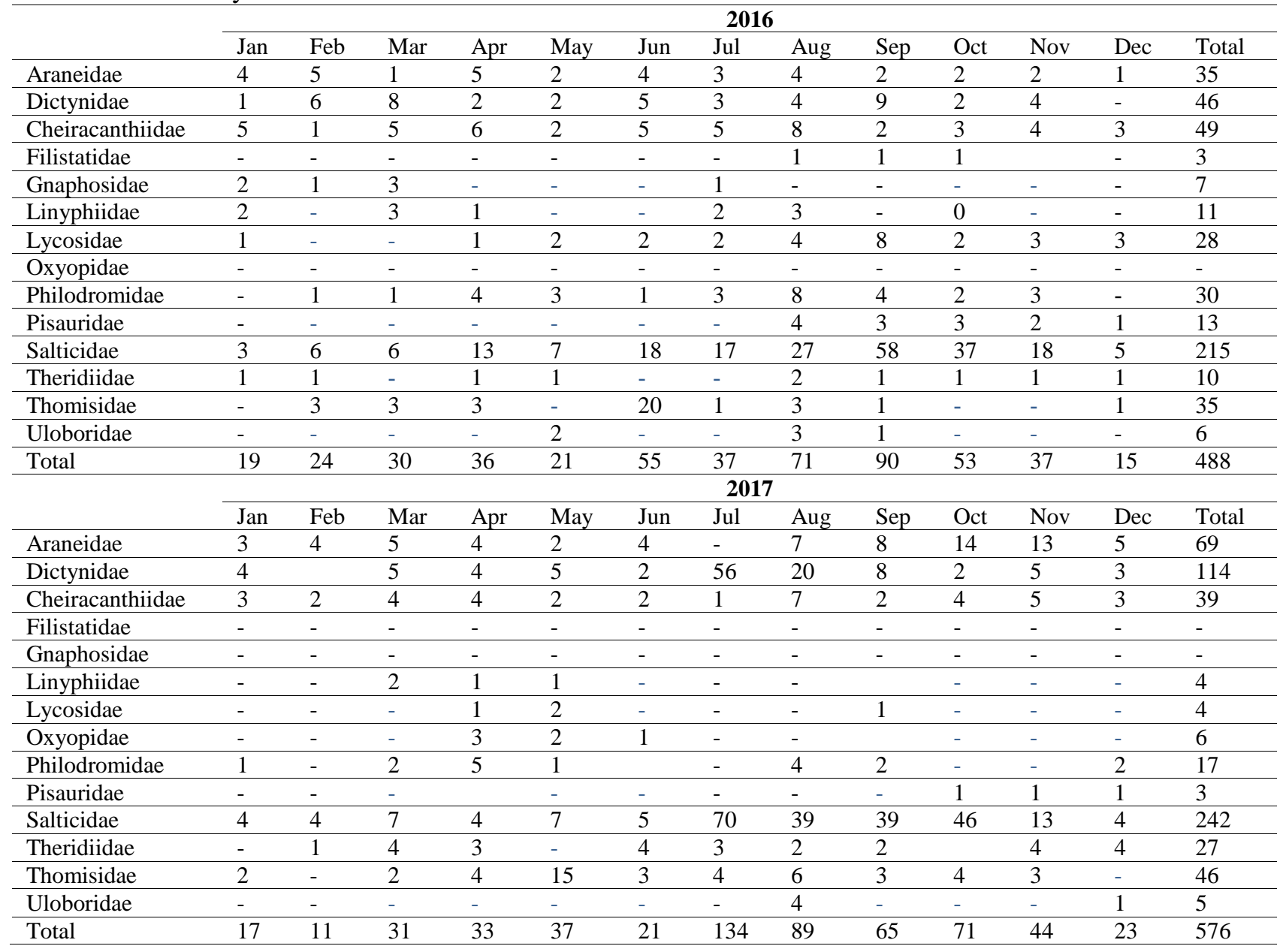




\section{D) Population density of spider families collected from Ornamental plants.}

Ornamental plants, Basil, Thuja, Duranta "Gold", Bottlebrush, Amaranthus, Zinnia, Roses, Geraniums, Poinciana, camel's foot tree, D. sissoo and Gazania were inspected in 2016 and 2017 years. The collected spider families were sorted in table (6). For the annual census of all families, 488 and 576 individuals were recorded from Thirteen and twelve families for 2016 and 2017 years respectively. Four peaks were formed in April, June, September and November by 36, 55, 90 and 37 individuals respectively in 2016 year, however in 2017 year, three peaks were formed in May, July and October by 37, 134 and 17 individuals respectively.

As for total individuals per family, Salticidae was the most abundant in both study years with the highest number of individuals over the year, population was 215 and 242 individuals in 2016 and 2017 years respectively. In 2016 year, the families; Cheiracanthiidae, Dictynidae, Araneidae, Thomisidae, Philodromidae and Lycosidae ranked the second position, their population were $49,46,35$, 35,30 and 28 individuals respectively, while the rest of the families in the same year were represented in small numbers not exceeding 13 individuals. In the second year 2017, the families Dictynidae, Araneidae, Thomisidae, Cheiracanthiidae and Theridiidae were recorded the second order of the census after the family Salticidae, where the numbers were 114, 69, 46, 39 and 27 individuals respectively, while the rest of the families in the same year were represented in small numbers not exceeding 17 individuals.

Few numbers of the families Filistatidae and Gnaphosidae appeared timidly in 2016 samples with an annual total of 3 and 7 individuals, respectively, and completely absent in 2017 samples. Also the first appearance of the Oxyopidae family on medicinal plants and aromatic in April 2017 in low numbers for a period of three months, 3, 2 and 1 respectively. Also, the first appearance of the Oxyopidae family on ornamental plants was in April 2017 in a few numbers and for three months in numbers of 3,2 and 1 respectively. This result indicated that spiders were active during summer months. This result was in agreement with those of Uetz (1975), Abdel Moneim et al. and (2003) Rizk et al. (2012) who found that summer was the season of highest abundance for spiders with no significant differences among locations. Duffey (1975) concluded this result as dense and compact vegetation provides shade and humidity, which composes appropriate conditions especially for small spiders of the families Linyphiidae and Theridiidae. These spiders are exposed to loss of water more than larger ones, thus, find hiding places in numerous tiny spaces of such habitats.

\section{ACKNOWLEDGMENTS}

Authors express their deep gratitude to the members of Shandaweel Agricultural Research Station for their help, support and cooperation. We also express sincere gratitude to colonel Hisham Kamal El-Din El-Hennawy, Arachnology Specialist (spiders and scorpions) for revising the identification, identifying the difficult specimens during this investigation and reviewing the manuscript.

\section{REFERENCES}

Abdel Moneim, H., S. Zalt, M. El-Naggar and A. Ghobashy (2003) Spider diversity in relation to habitat heterogeneity and an altitodinal gradient in South Sinai, Egypt. Egyptian j. Biol. (5): 29-137.

Ahmed, H. S. K., M. A. M. Mohafez, S. A. S. Baghdadi and A. M Abdelrsoal (2014) Seasonal fluctuations of spider populations on Pomegranate and Orange orchards in Assiut governorate. J. Agric. Env. Sci. Dam. Univ., Egypt. 13 (3): 15-30.

Angeli, G., D. Forti and C. Pesarini (1996) Epigeic spiders (Aranea) in apple and pear orchrads in Trentino. Redio, 79: 113-121.

Berg, M. A., S.A.S. Dippenear, V.E. Deacon and S.H. Andeson (1992) Interaction between citrus psylla, Trioxaerytreae(Hem.:Trioxidae) and spider in an unsprayed citrus orchard in the Transvaal Lowveld. Entomophaga, 37: 599-608.

Breene, R. G., D. A. Dean and J. R. R. L. Meagher (1993) Spiders and ants of Texas citrus groves. Florida Entomol., 76: 168-170.

Cardenas, M.; F. Ruano; P. Garcia; F. Pascual and M. Campos (2006) Impact of agricultural management on spider populations in the canopy of olive trees. Biological Control, 38 (2): 188-195.

Costello, M.J. (1997) Abundance of spiders and insert predators on grapes in Central California, $\mathrm{j}$. Arachnology, 27: 531-538.

Duffey, E. (1975) Habitat selection in man-made environments. Proceeding of the $6^{\text {th }}$ International Aracknological Congress, 53 -67. Amsterdam.

EI-Heneidy, A. H., A. A. Ibrahim, Y. H. Fayad and G. M. Moawad (1996) Survey and population dynamics of common true spiders in Egyptian cotton fields. Annals of Agric. Sc., Moshtohor, 34(3): 1177-1187.

El-Hennawy, H. K. (2017a) A list of Egyptian spiders (revised in 2017). Serket, 15 (4): 167-183.

El-Hennawy, H.K. (2017b) Illustrated key to spider families of Egypt (Arachnida: Araneae). Serket, 15 (4): 184-208.

El-Sebaay, M.M.I. (2003) Studies on some true 
spiders associated with certain fruit trees in Ismailia Governorate. M. Sc. Thesis, Fac. Agric. Al-Azhar Uinv., 113 pp.

Foelix, R. F. (1996) Biology of spiders. Harvard University Press, Cambridge, MA, USA. 330 pp.

Ghabbour, S.I., A.M. Hussein and H.K. El-Hennawy (1999) Spider population associated with different crops in Menoufeya Governorate, Nile Delta, Egypt. J Agric. Res. 77 (3):1163 -1179.

Greenstone, M.H. (1999) Why a symposium on spiders in agroecosystems now. J. Arachnol., 27: 267-269.

Habashy, N.H., M.M. Ghallab and M.A. Rizk (2005) Spider populations associated with different types of cultivation and different crops in Fayoum Goveraorate, Egypt. Serket, 9 (3): 101-107.

Hendawy, A.S. and H.A. Abul-Fadl (2004) Survey of the true spiders community and its response to chemical and organic fertilizers in the Egyptian corn fields. Egyptian j. Biol. Pest Control, 14(1):231-235.

Hodge, A.M. (1999) the implications of intraguild predation for the role of spiders in biological control. The journal of Arachnology, 27: 351-362.

Hussein, A.M., H.K. El-Hennawy and A.A. Sayed (1998) Biodiversity of spiders (Araneae) in the western desert of Egypt in relation to agriculture and reclamation. Bull. Fac. Agric. Cairo Univ., 49: 597-610.

Ibrahim, A.A., S.A. Shairra and F.S.I. El-mahdi (2012) Studies on the occurrence of true spiders as natural enemies in many Egyptian fields. The Journal of Basic \& Applied Zoology, 65, 1-3.

Jocqué, R. and A.S. Dippenaar-Schoeman (2006) Spider Families of the World.Royal Museum for Central Africa. 336 pp.

Kaston, B.J. (1978) How to know the spiders. W.C. Brown Co., Dubuque, Iowa, USA. 722 pp.

Malony, D., F.A. Drummond and R. Alford (2003) Spider predation in agroecosystem: can spiders effectively control pest populations. Technical Bulletin. Main agricultural and forest experiment station, P. 190.

McDonald, B. (2007) Effects of vegetation structure on foliage dwelling spider assemblages in native and non-native Oklahoma Grassland habitats. Proc. Okla. Acad. Sci. 87: 85 - 88.

McPeek M.A. (1990) Behavioral differences between Enallagma species (Odonata) influencing differential vulnerability to predators. Ecology, 71: 1714-1726.

Meehan C.J., E.H. Olson and R.L. Curry (2008) Exploitation of the Pseudomyrmex-Acacia mutualism by a predominantly vegetarian jumping spider (Bagheera kiplingi). 93 ${ }^{\text {rd }}$ ESA Annual Meeting.

Meehan C.J., E.J. Olson, M.W. Reudink, T.K. Kyser and L.R. Curry (2009) Herbivory in a spider through exploitation of an ant-plant mutualism. Current Biology, 19(19): R892-93.

Metwally, A.M., M.E. El-Naggar, M.H. Mowafi and M.A. Mohafez (2002) Spiders associated with economic plants in Sohag, Egypt. Serket, vol. 8(1): 24-28.

Mohafez, M.A.M., T.M.M. Al-Akraa and M.A.M. El-Danasory (2010) incidence and seasonal fluctuation of true Spiders inhabiting different Orchard trees at Sohag governorate J. Plant Protection and Pathology, Mansoura Univ., 1(5): $241 \cdot 250$.

Nyffeler, M. and G. Benz (1987) Spider in natural pest control: arevew. J. Apl. Entomol. 103 (1-5): 321-339.

Petrunkevitch, A. (1939) Catalogue of American spiders. Part one. Transactions of the Connecticut Academy of Arts and Sciences, 33: 133-338.

Power, M.E., J.C. Marks and M.S. Parker (1992) Variation in the vulnerability of prey to different predators: community-level consequences. Ecology, 73: 2218-2223.

Preston, F.W. (1948). The commonness and rarity of species, Ecology, 29: 254-283.

Rajeswaran J., P. Duraimurugan and P.S. Shanmugam (2005) Role of Spiders in agriculture and horticulture ecosystem. J. food, Agric. Environ., 3(3 \& 4): 147-152.

Riechert, S.E. (1981) the consequences of being terrestrial; spiders, a case study. American Naturalist, 117(6): 871-892.

Riechart, S.E. and Lockley, T. (1984) Spiders as biological control against, Ann. Rev. Entomo. 29: 299-320.

Rizk M.A., G. M.E. Sallam, N.A.I. Abdel-Azim and M.M. Ghallab (2012) Spider Occurrence in Fields of some Medical and Ornamental Plants in Fayoum - Egypt. Acarines, 6: 41-47.

Rosenheim, J.A., L.R. Wilhoit and C.A. Armer (1993) Influence of intraguild predation among generalist insect predators on the suppression of an herbivore population. Oecologia (1993) 96: 439-449.

Sallam, G.M. (1996) Studies on true spiders in Giza Governorate. M.Sc. Thesis. fac. Agric., Cairo Univ., 139 pp.

Sallam, G.M. (2002) Studies on true spiders in Egypt. Ph.D Thesis, Fac. Agric. Cairo Univ. 144 pp.

Sallam, G.M.E. and N.A.I. Abd El-Azim (2016) Abundance of spiders on grapevines and apple trees in El sadat city, Menofia Governorate, Egypt. Indian Journal of Arachnology 5 (1-2): 42-60.

Scheidler, M. (1990) Influence of habitat structure and vegetation architecture on spiders. Zoologischer Anzeiger 225, 333 -340.

Southwood, T.R.E. (1978) Ecological Methods with 
particular reference to the study of insect population. Chapman and Hall, London: $524 \mathrm{pp}$.

Uetz, G.W. (1975) Temporal and special variation in species diversity of wandering spiders (Araneae) in deciduous forest litter. J. Environ. Entomol. 4:719- 724.

Wagner, J.D. and D.H. Wise (1996) Cannibalism regulates densities of young wolf spiders: evidence from field and laboratory experiments. Ecology, 77: 639-652.

Wissinger, S.A., G.B.G.L. Sparks, W.S. Rouse, W.S.
Brown and H. Steltzer (1996) Intraguild predation and cannibalism among larvae of detrivorous caddisflies in subalpine wetland. Ecology, 77: 2421-2430.

Wolak, M. (2000) The spider fauna of balks. Proceeding of the $19^{\text {th }}$ European Colloquin, of Arachnology, Arhus. European Arachnology: 229-236.

World Spider Catalog (2018) World Spider Catalog. Natural History Museum Bern, online at http://wsc.nmbe.ch, Version 19.5, accessed on \{October 2018\}. doi: 10.24436/2. 